\title{
The Effect of Storytelling Picture Book on Reading Readiness of Group B Kindergarten Children in Padang
}

\author{
Endri Yanti ${ }^{1}$ and Delfi Eliza ${ }^{2}$ \\ ${ }^{1}$ Early Childhood Education Program, Faculty of Education, Universitas Negeri Padang, Padang, Indonesia \\ endriyanti.spd.2013@gmail.com \\ ${ }^{2}$ Early Childhood Education Program, Faculty of Education, Universitas Negeri Padang, Padang, Indonesia \\ deliza.zarni@gmail.com
}

\begin{abstract}
The purpose of this study to determine the effect of storytelling picturebook activity on the group B children's reading readiness kindergarten in the city of Padang in 2018. The method used an experimental method using a pretest-posttest control group design. Data were analyzed using $T$ test to calculate the two averages. The population of this research is all kindergarten children Group B located in the District of West Padang, Padang city. The sample in this study 18 children in group B TK Negeri II as an experimental group and 18 children in group B TK Aisyiyah 24 JondulRawang as a control group. The results of this study indicate that there are significant differences in reading readiness of children in group B were given treatment by using storytelling picture book by Wordbook, while reading readiness in children given the treatment group B using pictorial word card is not a significant difference.
\end{abstract}

\section{Keywords: Picture Book Storytelling, Wordbook, Reading Readiness}

\section{INTRODUCTION}

Reading is a uniquely human activity and capability. The ability to read is not automatic because it must be preceded by activities and reading habits are a manifestation of their interest in reading. Foster interest in reading early will make it easier to realize the reading culture and traditions of literacy in children in the future. Reading will enrich children, rich vocabulary, improving speaking skills, increase knowledge, and increase creativity. But children today are more like watching television and playing games. Plus, the rapid advances in technology, such as the proliferation of smart phones, causing children further away from other activities such as reading and more bring positive benefits.

Based on the fact that the public interest and reading habits Indonesia is still low. UNESCO statistical data in 2012 mentioned index reading interest in Indonesia reached 0.001. According to UNESCO's education development index, Indonesia was number 69 of 127 countries. This fact is supported by yearly survey of the Central Statistics Agency (BPS) on reading and watching the children of Indonesia, which was last done in 2012. It is said, only $17.66 \%$ of Indonesian children who have interest in reading. Meanwhile, who has a $91.67 \%$ interest in watching achieve.

The results of another assessment by a team of USAID to the third grade elementary school 15941 children spread across 7 provinces in 2012-2015 to mention that almost all children are fluent reading, but do not understand the meaning of the passage. Factors underlying the low interest in reading the Indonesian community there is no readiness to read instilled from an early age. Not a few children start school with poor learning progress due to a lack of readiness to read. This of course has consequences that are vital and adverse impact on the children themselves.

The result of research interviews to some kindergarten teachers and principals in the district of Padang Group B West, most of the teachers do not understand the concept of reading readiness, some less precise, and few have understood correctly. In this case the reading readiness beginning in childhood, teachers still find many obstacles associated with several components of reading readiness as the ability to ring a certain letter $(\mathrm{d}, \mathrm{b}, \mathrm{q})$, find similarities end of the sound, and the understanding of the word sounded.

The results of observations prove that more children are given an activity sheet kids (LKA) in the form calistung than an activity which was calculated to support the child's reading readiness. Media or less interesting learning activities and the lack of opportunity and support given to children, the cause lack of reading readiness of children. These facts show a glimpse of the importance of learning activities should be made as simple as possible, so that children have the readiness to read and master the material provided.

The views expressed by Eliza (2014: 3) state that it is important to note the readiness of reading from an early age because it has a major influence on the success in the future. The importance of reading readiness has also been 
a lot of in and Alisinanoglu discussed in several studies. The first study by Cetin and Alisinanoglu (2013: 161), about the reading readiness program prepared for children aged 3-6 years were held for 8 weeks had a positive effect on the consciousness printing/writing (print awareness). This study provides an understanding that in order to raise awareness of printing/writing (print awareness) takes a reading readiness program given at an early age.

A second study by Elliot and OlliF (2008: 551) states that although children usually do not learn to read until the age of five or six years, from birth to the first five years are the most important for the development of pre-literacy. To be successful in learning to read, prereaders must have knowledge of the alphabet, phonological awareness, lettersound correspondence, awareness of print concepts and some experience of using writing as a form of communication. Some of this knowledge is the aspects of reading readiness. These aspects are the foundation for the child's reading success in the future.

A third study of Luther (2012: 36), states that in order to form a strong education, it is important to develop basic skills in the early lives of young children. In this case the reading is the most important content. Without a solid understanding of literacy skills, children must struggle to read proficiently as they grow older. In addition, in order to control the continuous cycle of poverty from generation to generation, children need a strong foundation in reading and literacy skills. Early childhood teachers can help poor children by continuing to think and find new ways and interesting to teach reading.

reflect / describe

the survey results and observations and interviews, reading readiness of children is an important thing to consider during the process of learning in kindergarten. The older child has a reading readiness possibility to successfully participate in education at the next level is greater than children who do not have readiness.

Age 6 years is the transition from early childhood to the elementary school where there are differences in the learning demands on the second level. Compared with the pre-school, school learning activities mostly done independently and directed to have the academic skills such as reading and writing. Based on these differences early childhood educators should understand the extent of readiness memambaca in children before putting it into the primary school level

In terms of supporting the readiness of reading to younger children in kindergarten, learning activities used by teachers should attract the attention of children and foster children's interests in terms of language. One of the learning activities that can support children's learning and the teacher is storytelling.

Miller and Pennycuff (2008: 36), shows that in addition to improving the ability to speak and the academic field of reading and writing, telling stories (storytelling) also promotes creativity and imagination andak arts in education, improve the social skills of children and motivate children in learning. Storytelling activities make children not only proficient in communication but also can improve the cognitive development of children through imagination and creativity of children after getting a stimulus in the form of storytelling.

Accordingly, Cutspec (2006: 1), in a study mentions that storytelling effect on the literacy skills of children and make children motivated to improve their communication skills. Storytelling can be used to simplify the various concepts, both the concept of learning and the concept of life to children, in addition to the children also like to listen to stories. Dorrat (2016: 19), describes the storytelling appropriate for young children because it can be used for a variety of themes and can be done in various places and conditions. Flexible use of this storytelling make the teachers can develop the creativity in storytelling activities. One form of storytelling that can be used is storytelling picture book using Wordbook.

The research result Arbie (2015: 6) states that the use of picture book (books illustrated) in kindergarten is done by teachers always get children to read before (opening) or after learning (closing) in the class, in addition to learning by using picture book in class is done by means of holding storytelling activities by teachers, and teachers to train children to express what has been read and what has didengae of the storytelling activities. Thus the results of this study support that activity using a picture book storytelling can improve children's reading readiness.

While the research conducted Montang (2015: 1), et.all mentioned that tell a story using picture books that have writing (Wordbook), influenced in favor of reading ability. This is because many types of unique words contained in the text book picture story, so the vocabulary is owned by the child to be increased. From these results it can be seen that the books that have writing (Wordbook) is one way to develop language skills of children, especially in improving reading skills. With their unique vocabulary contained in the Wordbook, then the child's vocabulary be increased so as to foster interest in reading in children.

Based on previous research and the fact the problems in the field that have been described, it is necessary to do research on the influence of storytelling picture book to the child's reading readiness in Group B kindergarten, Padang. Where researchers will look at the influences of storytelling picture book using the word book and picture book storytelling using pictorial word card to the child's reading readiness.

\section{RESEARCH METHODS}

This study was conducted using the method of experimental design pretest-posttest control group design. Selection of the design is intended to measure the child's reading readiness before and after the treatment given to the experimental group and the control group. The treatment is given in the form of storytelling picture book in the form of activity for the experimental group using Wordbook, to a control group using a wordless book.

Data collection techniques in this study using the instrument that is data about children's reading readiness. Type of instrument used in the form of non test instrument that has been made by 
researchers conduct tests and interviews shaped in the form of questions on child views of how well children master the material that has been taught. This instrument has been tested through its validity by experts. The sampling technique was conducted by multistage random sampling technique. Data analysis techniques in this study using a test $\mathrm{T}$. To test the hypothesis can be done it is necessary to test the analytical requirements of normality and homogeneity test. Normality test is done by using test Liliefors and homogeneity tests performed using the Bartlett test.

\section{RESULTS AND DISCUSSION}

After analyzing the data make use of $\mathrm{T}$ test, then the discussion centered on four research hypothesis has been substantiated:

A. Child's reading readiness before being given treatment using a worksheet children (LKA) was lower than after a given treatment using pictorial word card.

Based on the calculation results of $\mathrm{T}$ test to compare results before and after treatment in the control group obtained $\mathrm{t}=-3.85<\mathrm{t}$ table $=2,04$ at the significant level $\alpha=0.05$. Thus the hypothesis that children's reading readiness before being given treatment using worksheets $n$ children is lower than using Wordbook accepted.

The average difference in score reading readiness before being given treatment or pretest value $=55.25$, while the given treatment after use Wordbook $=80.35$. The results as a whole show that storytelling picture book using Wordbook more effective than given LKA.

Implementation of reading by using LKA cause the child is less interested in the learning process, so that the reading skills of children less than optimal. The application of the conventional method used by the teacher method drill, such as the teacher gives pertintah on children so that children pick up a book (LKA) or magazine, the teacher asks the children open a page that has been determined, the teacher wrote on the board the teacher read, later children imitating, and children were told to forward to learning to read in front of the class.

In addition to the methods applied are less effective in improving children's reading readiness, teachers have not been using varied media in the learning process, so boring for the child and the child is less enthusiastic in the classroom. Therefore, the conventional method is not effective LKA administration implemented in learning to read in kindergarten.

These results indicate that the ratio of children's reading readiness more effective use of storytelling picturebook by Wordbook. Wordbook or picture books can be defined a device / media that contains messages that can reflect/describe the contents of a story. Picture books is the most commonly used. This is because children generally prefer pictures rather than text, especially if the images are presented susai toggled and a good image requirement, will add to the spirit of the child in the following study.

Endirano (2019: 7), picture books are books that are presented using text and illustrations or pictures. Using the method illustrated story to introduce the basic aspects of reading in early childhood is one of the effective means used by teachers. Retnowati, et.all (2017: 95) states, tells the story book can effectively improve the reading skills of children aged 5-6 years. One of the principles that are applied instituted early childhood education is to learn while playing, or play while learning and learning must be fun and inovation, and tailored to the child's developmental level. Through the story method using these picture books children will be able to recognize the letters easier and more enjoyable.

B. Child's reading readiness before being given treatment using achildren worksheet (LKA) was lower than after a given treatment using pictorial word card.

Based on the calculation results of $\mathrm{T}$ test to compare results before and after treatment in the control group obtained $\mathrm{t}=-3.45<\mathrm{t}$ table $=2,04$ at the significant level $\alpha=0.05$. Thus the hypothesis that children's reading readiness before being given treatment using a worksheet children (LKA) was lower than after a given treatment using pictorial word card accepted.

Reading readiness of children in the control group the same as the experimental group is to give children worksheet (LKA) to children. Teachers teach reading by providing the materials on LKA. If the material is understood to read beginning in early childhood in LKA does not comply with standards for learning in early childhood. Such material may be taught to the next level of education is primary school.

According to the research by testing the ability of reading readiness of children by calculating the average pretest score of children in the control group gained 53.70, while the post-test values were obtained after a given treatment that is 72.45 . During the beginning teacher to teach reading in children by using LKA looks uninterested during the learning activities and children are less motivated. So the process of reading in early childhood learning to walk less effective and does not provide optimal results in the child's reading readiness.

From the research and views of the average value after a given treatment pictorial word card looks more effectively applied to reading readiness of children in kindergartens, compared to using LKA.

Dhieni in Wulandari (2014: 37) states illustrated word cards, including the type of visual media, the recipients of the message (children) will receive information through the senses and vision, because the message will be delivered poured into symbols of visual communication. In addition, Aulia (2011: 84) adds the image to have great power in responding to the child's brain. Through visualization media (picture), in addition to child captures sound pronunciation of a particular case or a particular name.

Exact pictorial word card is used to introduce the concept of reading in children beginning in kindergarten with images as symbols. Media picture word card greatly simplifies the teacher in the process of teaching reading to 
children. With this media, children will easily absorb the purpose of learning about the concept of reading starters and facilitate teachers in the teaching process.

C. Child's reading readiness after being given treatment using a storytelling picture book using the word book is higher than using pictorial word card

Based on calculations using the Test $\mathrm{T}$ that $\mathrm{t}=$ $6.25>\mathrm{t}$ table $=2,04$ at the significant level $\alpha=0.05$ thus rejected and the alternative hypothesis is accepted. The average difference in score reading readiness before being given treatment $=57.50$, lower than after being given treatment given storytelling by using Wordbook $=78.65$. These results suggest that alternative hypotheses have indicated that there are differences in readiness to read a child after being given treatment using a storytelling picture book using the word book is higher than word cards pictorial results show after being given treatment using storytelling picturebook use Wordbook have a significant influence on the readiness of the child's reading , The results of this research was supported by the opinion expressed by Cutspec (2006: 1), storytelling effect on the literacy skills of children and make young people motivated to develop communication skills. This statement is supported by the results of research that says a media Zonna convey various messages in the form of a book that is packed in the text or images. This means telling a story with a picture book with a few sentences, can improve the reading skills of preschool children.

According Endriano (2019: 9) on the research results illustrated story book contains illustrations and written ext messages. Both of these elements are important elements in the story. These books contain a variety of themes that are often based on the experience of the child's daily life. Characters in this book can be either human or animal. Picture books in this study show human qualities, character and needs, so that children can understand and relate to personal experience.

Januarini (2016: 4) defines picture cards are small pieces of card which is usually the size of a post card, each card there is writing one word and image and this card is used to help children learn to recognize words and letters are taught by showing pictorial word card, then the children mentioned the letter that is under the picture. These activities make learning as children are not interested in following the learning. Rahadi (2003: 27) points out the weakness of media images show only the eye of sense perception, limited size can only be viewed by a group of children, images are interpreted personally and subjectively, served in a small size, making it less effective in learning.

Based on the results of hypothesis testing and is supported by the results of previous studies, it can be said that the child's reading readiness after treatment given storytelling picture book using the word book is higher than using the word cards with pictures

\section{CONCLUSION}

Based on the results of the exposure on the results and discussion, it can put forward some conclusions as follows:

Child's reading readiness before being given treatment using a worksheet children (LKA) was lower than after a given treatment using pictorial word card. Based on the calculation results of $\mathrm{T}$ test to compare results before and after treatment in the control group obtained $\mathrm{t}=-3.85<\mathrm{t}$ table $=2,04$ at the significant level $\alpha$ $=0.05$

Child's reading readiness before being given treatment using a worksheet children (LKA) was lower than after a given treatment using pictorial word card. Based on the calculation results of $\mathrm{T}$ test to compare results before and after treatment in the control group obtained $\mathrm{t}=-3.45<\mathrm{t}$ table $=2,04$ at the significant level $\alpha$ $=0.05$.

Child's reading readiness after being given treatment using a storytelling picture book using the word book is higher than using pictorial word card Based on calculations using the Test $\mathrm{T}$ that $\mathrm{t}=6.25>\mathrm{t}$ table $=2,04$ at the significant level $\alpha=0.05$ thus rejected and the alternative hypothesis is accepted.

\section{REFERENCES}

[1]. Alisinanoglu, Fatma and Ceti, OzlemSismek, "Investigation of the Effects of Writing and Reading Readiness Studies," on of the Print Awareness of Pre-School Children, Vol.5, International Journal of Educational, pp.161

[2]. Cutspec, Patricia A, "Oral Storytelling Within the Context of the Parent-Child Relationship", Volume 1, Number 2. Talaris Research Institute. 2006. pp. 1

[3]. Dorrat, Loise, "Music, Storytelling and Dance in Early Childhood Educating Young Children, Learning and Teaching in the Early Childhood Years", 2016. Vol. 22. pp. 19

[4]. Eliza, Delfi, "Reading Readiness of Kindergarten Students of At-Taqwa Mosque, East Jakarta", Indonesian Journal of Early Childhood Education Studies. 2014 Vol.3, No. 1. pp.3

[5]. Endriano, Rizki, "Illustrated Stories Media Development to Improve Early Childhood Literacy in RaudhatulAthfalMashytoh 13 SukorajaLor", IAIN Purwokerto 2019. pp.7

[6]. Januarini, Hesti, "Application of Model TGT Assisted Media Picture Cards to Improve Children's Language Development", Vol 4, E Journal PG ECD Ganesha Education University, 2016. pp. 4

[7]. Luther, Vicki, "The Riches of Literacy: Teaching Reading Skills to Young Children Living in Poverty", Macon State College. 2012. Vol. 46. pp.36 
[8]. Montang, Jessica L, Michael N. Jones and Linda B. Smith, "The Words Children Hear: Picturebooks and The Statistics for Language Learning", Physicological Associations for Science, sagepub.com/journals.permission.nav. 2015. pp. 1

[7]. Olliff, B, AE Charleem and M. Elliot, "Developmentally Appropriate Emergent Literacy Activities for Young Children: Adapting the Early Literacy and Learning Model, Early Childhoo" J Educ, Vol 35. 2008. pp. 551

[8]. Pennycuff, Lisa, and Miller, Sara, "The Power of Story: Using Storytelling to Improve Literacy Learning", Journal of Cross-Diciplinary Perspectives in Education. Vol 1.2008. No. 1. pp.36

[9]. Rahadi, "Weakness Picture Cards", Yogyakarta State University, 2003: 27

[10]. Retnowati, et.all. "Effectiveness of Picture Story Books Reading to Increase Kindergarten in Children", 2018. pp.95ResearchGate

[11]. Wulandari, Marlina, "Improving Media Literacy Starters Using Picture Cards for Kids in kindergarten Arjuna Group B GadingsariDayu Sanden, Bantul". 2014 State University of Yogyakarta

[12]. zone, LinaMarita, "Using the Picture Story Book Children Reading Ability Menumuhkan Group B at TK Pertiwi 1 TirtobinangunNganjuk", State University of Surabaya 